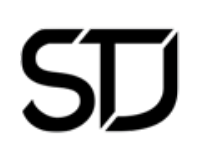

\title{
The rediscovery of spiritual practices within Protestantism
}

\author{
George Marchinkowski \& Pieter G.R. De Villiers \\ University of the Free State \\ Bloemfontein, South Africa \\ pgdevilliers@gmail.com
}

\begin{abstract}
In a first part this article investigates the older negative view of spiritual practices especially in Protestant contexts. It then spells out the reasons for the growing interest in and reappraisal of spiritual practices in recent times. This development reflects and confirms a special awareness of their powerful role in spiritual life and illuminates their nature and meaning. It further analyses how the growing interest in spiritual practices is a result of recognising their role in the spiritual heritage that empowered faith communities from earliest times and that are not restricted by and to confessional boundaries. The article, on the other hand, concludes with a discussion of the dynamic way in which spiritual practices are embedded in particular contexts within faith communities and, therefore, are also expressed in and through particular confessional characteristics.
\end{abstract}

Keywords

Spirituality; spiritual practices; spiritual disciplines; spiritual formation

\section{Introduction}

Confessional arguments have played a decisive role in criticism of and resistance against spiritual practices. Wakefield (1983:363), for example, wrote about Catholic and Protestant understanding of spiritual practices, "the one will lay more emphasis in our own effort towards God, of union consummating purgation and illumination, whereas for the other all is of God's justifying mercy and begins the mystical union, which is the first work of saving grace in our hearts". Key terms in this remark are effort, justifying mercy and grace. Spiritual practices in non-Protestant contexts were seen as attempts to earn grace, that is, obtaining salvation through meritorious work and action, which, again, contrasted with the central 
Protestant teaching of justification through grace and by faith alone. ${ }^{1}$ Sheldrake (1995:207) expresses a similar sentiment in another, broader context, "In fact, until recently, the word 'spirituality' was viewed with some suspicion by Protestants. They preferred terms such as Godliness, piety, holiness of life or the devout life because these seemed less tainted than 'spirituality' with the erroneous doctrine of works-righteousness. The situation has changed substantially."

Recent decades saw the need to reflect on such confessional perspectives on spiritual practices, especially since the renewed interest, also in Protestant circles, in both ancient spiritual practices that existed from early Christianity, and contemporary (newly shaped) spiritual practices. It raised the question to what extent spiritual practices reflect or relate to a particular confessional position, if at all, and also about the relationship of doctrine and theology of a particular faith community with its life praxis and spiritual practices. This article will respond to these questions by analysing contemporary research on spiritual practices by both Protestant and non-Protestant scholars. It will investigate whether and to what extent spiritual practices there are unique features in confessional reflections on spiritual practices.

\section{A negative view of spiritual practices}

Protestant attitudes towards spiritual practices have not always been positive. In 1991, a publication of Driskill ${ }^{2}$ with the title Protestant Spiritual

1 For a more hostile criticism and for an insight in the cultural wars that define the debate about spiritual practices, cf. DeWaay (2005:n.p.), "To hear evangelicals like Dallas Willard and Richard Foster tell us that we need practices that were never spelled out in the Bible to become more like Christ or to get closer to God is astonishing. What is more astonishing is that evangelical colleges and seminaries are requiring their students to study practices that are relics of Medieval Rome, not found in the Bible, and closely akin to the practices of many pagan societies." Rome is for him Catholic Rome from Medieval times with its ideal to "rule over the world." He objects against spiritual practices because, amongst others, they are not prescribed in the Bible, overlook humanity's "total depravity", overestimate human "ability", and are more "akin to Eastern Religion than Biblical Christianity."

2 Joseph D Driskill is a professor of Spirituality at the Disciples Seminary Foundation at Pacific School of Religion in Berkeley, California, and ordained by the Disciples of Christ in the USA. He received recognition for his work in Spirituality Studies when he was elected President of the Society for the Study of Christian Spirituality (SSCS). 
Exercises. Theology, History and Practice, was one of the few that had appeared in the twentieth century within Protestant circles. It is striking that his work was to a large extent apologetic in nature, characterised by an extensive attempt to legitimise itself. It dealt extensively with the discomfort Protestants feel about matters relating to Spirituality and with spiritual practices in particular. So endemic was this apprehension that the book regards this discomfort as virtually "wired" into the DNA of Protestantism.

Driskill explores some possible reasons why Protestants neglect the study of spirituality and spiritual practices. One reason is to be found in Protestantism's traditional areas of strengths that kept Protestants from appreciating spirituality and its practices. This neglect is a result of more scholastic and puritanical influences that contributed to a preference for foundational theology with its concentration on divine actions in God's redemptive work, rather than focus on matters regarding the individual's personal relationship with God or response to the gift of salvation. This was a consequence of their high regard for the primary place of the Word as the locus of revelation and the container of truths for the spiritual life, but also of the conviction that humanity was totally depraved, incapable of "good works", and, therefore, in no way able to contribute to its salvation. This happened despite the attention to ethical reflection and work ethic, including social action, which tended to overshadow the Protestant conviction that these responsibilities are birthed and formed in a life-giving relationship with God (Driskill 1991:4). Critical reflection was a strong feature of Protestantism, influenced by the demands of the enlightenment with its emphasis on reason and a rational approach to faith.

In tandem with this trend, an analytical paradigm prevailed in the theological discourse, with a concomitant side-lining of the more affective sources and practices of Christian life. Protestantism was often uncomfortable with the subjective and the experiential (Driskill 1991:6). Protestantism in its more mainline forms, was critical of a preoccupation with faith experiences and personal growth and preferred reflecting on the objective realities of Scripture as the reliable Word of God and doctrine as the teaching of the church. Driskill (1991:xii) notes these concerns in his remark that, 
believers can affirm the existence of God, the importance of the Scriptures and the need to hear the Word in sermons, but discourse that claims a personal relationship with God at an experiential rather than an intellectual level is largely discouraged.

And,

The derision mainline Protestants feel about a personal experiential relationship with God is reflected in their lack of attention to spiritual practices (Driskill 1991:xiii). ${ }^{3}$

Driskill further notes how this aversion to the experiential caused members to leave their mainline Protestant churches in protest and to join new charismatic and Pentecostal-type churches, or, also some Roman Catholic groups where their experience of God was acknowledged, appreciated and encouraged.

For Driskill (1991:xvi) this apprehension about spirituality and practices as faith experienced is ironic when one considers that Protestants do have a spirituality. There is merely a failure to recognise it as such. He further refers specifically to spiritual practices when he notes (1991:xviii) with appreciation that Protestants "have within their own tradition spiritual practices that are life giving ... provide a number of alternatives for spiritual growth."4 These practices encompasses prayer, bible study and well developed sacramental and liturgical rites.

3 Note the insertion of "mainline" here. Pietism with its strong experiential nature, was always a significant part of some Protestant contexts, but, then, it was a movement that belonged more to the periphery. The same is especially true of Pentecostalist and charismatic circles that, tellingly, represent one of the strongest movements within Protestantism in the twentieth century. Cf. Williams (2016) for a recent careful analysis of the role of experience, emotions and the subjective in Pentecostal worship contexts. This article, focusing on the therapeutic work through worship in a Pentecostal community, illustrates the way in which the body and emotions function in Pentecostalism. As such, it contrasts sharply with traditional confessions with their reserved attitude towards the experiential and the body. The article, is however, also valuable for its academic insights and its applied research through a case study of Pentecostal worship.

4 Cf. also Sheldrake (1995:207). 


\section{Reappraising spiritual practices}

Before analysing the reasons for the growing interest in spiritual practices in recent times, also and especially among Protestants, is discussed, it is necessary to illuminate what is meant by them. This can best be done by listing the more salient forms of practices.

Such an overview was done early on by Richard Foster, who published one of the earliest, books on spiritual practice for an English-speaking Protestant audience. ${ }^{5}$ In this bestselling book that sold more than 2.5 million copies, he systematized practices in a list of twelve different "disciplines" ${ }^{6}$ according to three categories. The "inward" disciplines comprised meditation, prayer, fasting and study. The "outward" practices were simplicity, solitude, submission and service. The corporate practices were confession, worship, guidance and celebration. Foster (1978:1) named these practices "classic:" they go back to early traditions and were practiced by generations of believers, so that they are "central to experiential Christianity". With

5 Richard Foster is a minister, academic and theologian in the Quaker tradition. His first book, Celebration of discipline. The path to Spiritual growth (1978), which surveys twelve of the ancient spiritual practices, has been reprinted in 1988 and 1998, selling over one million copies. He has also published Freedom of Simplicity (1981), Money, Sex and Power (1985) and Prayer: Finding the heart's true home (1992). Foster is an early marker of the beginnings of contemporary Protestantism's interest in spiritual practices.

6 DeWaay (2005) is especially critical of practices because they are called "disciplines" by Foster and, therefore, indicate the contribution of humanity to their salvation. Also common for practices is "exercises," under the influence of Ignatius of Loyola's classic work. Driskill's book (1991) is an example, of the use of this term. The complexity and richness of the term, is illustrated in a discussion of Waaijman (2007:7), who speaks of "exercises", describing them as "processes of appropriation", but adding that they are "innerly oriented on "purity of heart" as the practical objective (skopos) of spiritual exercises, looking for the receiving of contemplation (telos). A special nature of practices is illustrated when he links it with the practice of "virtues," which he describes as "both precondition and essence of spiritual practices; meditation and prayer; mystical transformation." (Cf. further the discussion on virtue below). It is such a link that should be kept in mind when one reflects on spiritual practices in a Protestant context - in which sanctification and the fruit of the Spirit are key themes. All this shows that the reading of practices in terms of merit, is naïve and uniformed. For other, more superficial comments, cf. Tim Keller, a Presbyterian minister (in the more conservative Presbyterian Church of America denomination) on the New Calvinist website ( $h t t p: / /$ www.newcalvinist.com/keller-richard-foster/) where the following remark about Foster's work is found: "But his advice is highly dangerous, for those who follow Foster and seek after an out-of-body experience to make contact with the eternal Creator, may be opening themselves to occult spiritual forces." 
this description he transcended confessional boundaries, noting that they speak to various constituencies. The spiritual practices of prayer and study, service and worship would have been familiar to Protestants, whilst solitude, contemplative prayer, meditation and confession would tend to be more "Catholic" practices.

Foster's work was soon followed up by other Protestant authors. Dorothy C. Bass ${ }^{7}$ and Craig Dykstra, ${ }^{8}$, for example, analysed both classic and contemporary forms of practices. They gathered a group of authors as part of their Valparaiso Project that reflected on various practices that would complement the traditional ones. ${ }^{9}$ Their investigations included newer practices that may sound strange to the uninitiated among Protestants, like honouring the body, hospitality, household economics, saying yes and saying no, keeping sabbath, testimony, discernment, shaping communities, forgiveness, healing, dying well and singing. They approached their work in a creative manner, modifying some of the practices, like, for example confession that became the practice of forgiveness (Bass 1997:8-12).

The same dynamics are to be detected in reflections of Barbara Brown Taylor who also writes within a Protestant context. ${ }^{10}$ In her bestselling book, $A n$ Altar in the world. A geography of Faith, (2009), she confirms the significant role of spiritual practices in the spiritual journey. She also reshapes and

7 Dorothy Bass, an Evangelical Lutheran, has published widely on this theme. She is the author of Receiving the Day: Christian practices for opening the gift of time and co-editor of Practicing our faith: a way of life for searching people and Our way: Christian Practices for living a whole life. Two of her books, co-edited, explore the implication of practices for ministry and theological education, Practicing Theology: Beliefs and practices in Christian life and For life abundant: Practical Theology, Theological Education and Christian Ministry. Her work thus reflects the ongoing and increasing investigation of spiritual practices in a Protestant context.

8 Craig Dykstra, a practical theologian, born into a Reformed Church of America family and ordained a Presbyterian, taught Christian Education at Princeton Theological Seminary and at Duke Divinity School. He, too, represents the increasing attention to spiritual practices in a Protestant context.

9 Valparaiso Project on the Education and Formation of People in faith was a project funded by the Lily Endowment, situated at Valparaiso university in Indiana, which sought to encourage the use of practices among Christian congregations of all (Protestant) denominations in the United States of America.

10 Barbara Brown Taylor is an episcopal priest and academic at Piedmont College, South Georgia, USA, who has published various books including An altar in the world. A geography of faith. (2009), Learning to walk in the dark (2015) and Holy Envy: Finding God in the faith of others (2019). 
transforms many of the traditional practices such as discernment, sabbath keeping and prayer in contemporary ways, while adding more other lesser known practices such as incarnation, groundedness, physical labour and benediction. Her book is another indication of how comprehensive, creative the approach to spiritual practices has become in Protestantism. It is an approach characterized by an openness to the original practices and the many and diverse needs of contemporary communities. She takes over traditional material but brings it into conversation with contemporary culture and with a generation which seeks to commune with the Divine outside the control and influence of the institutional church.

These three examples illustrate the great interest in and openness towards spiritual practices, and, moreover, the creative attempts to reflect on them and make them relevant for a contemporary audience.

\section{The power of spiritual practices}

From the above discussion, it has become clear that the various spiritual practices have been playing a powerful role in the spiritual journey of faith communities. This power is already evident in its potential to generate many and various forms of spiritual practices that transcend confessional boundaries. This power is also evident in other key features that deserve closer attention now.

\subsection{Spiritual practices as a powerful response to a spiritual need}

Spiritual practices have the ability to speak and respond to a fundamental spiritual need and desire. The spiritual need is found and exists within a context of alienation in which faith communities exist. The widely read publication of Bass and Dykstra, underscores that spiritual practices should be understood as a response to the alienation that exists within contemporary Western culture. They respond to the destructive patterns of living embedded in the contemporary neoliberal capitalist and secular ethos and the ravages that resulted from it. They indicate the yearning among people from such a context for a simpler lifestyle, a lifestyle in which there is wholeness, meaningful time and refreshment (Bass and Dykstra 1997:x; Bass 2002:16). In similar vein, McLaren (2008:14) describes the power of practices as helping communities within this experiential reality 
to "practice being alive", training them to see, hear and experience with increasing consistency and resilience, not just to survive, but to experience life in its fulness (McLaren 2008:17). ${ }^{11}$ Barbara Brown Taylor (2009:xiv) also describes how practices respond to "a longing - for more meaning, more feeling, more connection, more life". These practices have to do with spiritual needs of people, reflecting "shared activities that address fundamental human needs that, woven together, form a way of life" (Bass and Dykstra 1997:xi; Bass 2002:16). They offer an opportunity for transformation out of this situation and overcoming the alienation caused by it.

This aspect, therefore, illustrates an essential characteristic of spiritual practices. They are so powerful because they are relevant for and efficacious in the spiritual journey of all faith communities. A spiritual practice is not merely about a theological or practical reflection or theory, about the exotic and extraordinary, nor about a marginal or ascetic praxis that is the exclusive responsibility of a few, holy people or of church leaders. ${ }^{12}$ They have to do with the heart of faith, with the deepest spiritual needs of faith communities that reflect the desire to overcome alienation and spiritual "dryness"13 and to be transformed into a new way of life within their daily existence.

The spiritual nature of practices is illustrated by the remark how they "envision a way of life that is whole, a way of life that can be lived with integrity in our time", but ultimately the most important aspect is that this

11 Human beings "yearn for a richer and deeper understanding of what it means to live as Christian in a time when basic patterns of relationships are changing all around us" (Bass 1997:xiii; see also Norheim 2014:8).

12 Dykstra's early work highlights the harmfulness of individualistic, especially "clergy centric" paradigm which sees the minister up front doing all the spiritual practices while the congregation observe passively. In this respect, he leans on his mentor, Edward Farley. Dykstra thus argues for a communal model of practice (Dykstra 1991:35-37; also Norheim 2014:17) Norheim further traces the way Dykstra defines "practice" as "an ongoing, shared activity of a community of people that partly defines and makes them who they are" (ibid:18)

13 Foster (1978:xiii) like Driskill (discussed above) believes that spiritual practices provided the answer to his experience of a spiritual dryness. After three months in his first parish during which he was left with "nothing to give" to others, he turned toward the ancient practices as discussed by authors like Augustine of Hippo, Francis of Assisi and Julian of Norwich, among others, and realised (Foster 1978:xiii-xx) that they provided the support and sustained believers in their times of alienation and darkness. 
is about a life that is "whole, and touched by the presence of God" (Bass and Dykstra 1997:2). ${ }^{14}$ In this way, spiritual practices are not merely about virtues and about meaningful behaviour. They have a contemplative power, creating a space in which believers can be aware of the unfathomable divine presence. Ultimately spiritual practices are so powerful because they are about the mystery of God to which believers are directed.

\subsection{The dynamic nature of spiritual practices}

It is, secondly, noteworthy that authors on spiritual practices emphasize their important place, role and forms for more than two millennia. One of the earliest lists of practices attributable to the church, found in Acts 2:42-47, include various practices like hospitality, prayer, generosity and worship - all of whom testified powerfully to the integrity and reputation of the church. Also, from an early stage still other practices like pilgrimage, fasting, tithing and lectio divina were prominent in the life of religious orders and churches. They would, however, eventually also become a hallmark of ordinary Christian existence. They had the power to transform individuals and communities throughout the ages. ${ }^{15}$ Through this history, contemporary faith communities are, therefore, brought in touch with Christian traditions in which they are rooted, and which transcend narrow confessional boundaries. This shared history paves the way for acknowledging and celebrating the common heritage of all contemporary faith communities.

This desire to honour the sacred traditions of the past as the way to cope with alienation, reflects an awareness across confessions of their transformational power. Both Protestants and non-Protestants confirm this power. David Perrin, ${ }^{16}$ a Roman Catholic scholar, for example, writes (2007:267) about the ongoing relevance of traditions behind spiritual practices, "Spiritual

14 "Craig Dykstra argues for the use of Christian practices ... and claims that consumer culture has made the church unable to recognise and meet the (spiritual) hunger for meaning. In other words, consumer society has made the construction of the Christian self, something dubious and ambivalent" (Norheim 2014:16).

15 Bass and Dykstra therefore assert (1997:8; 2002:26) that, "practices are done in community over a period of time".

16 David Perrin, a Roman Catholic priest, professor of Theology at Saint Paul university, Ottawa, Canada, and later President of St. Jerome's University in Waterloo, Canada, is known for his important research on St. John of the Cross. He is also known for this 
practices are passed along in the forms of traditional rites, songs, readings, particular types of social outreach, along with countless other ways in which people have creatively constructed, expressed, explored, and deepened Christian spiritualties." There is not only a connection with past practices. The present-day believer is also actively involved in the broad and sweeping communal ancient rites that are practiced drawing near to God. They invite people to tell each other the stories of faith and to explain why they do the things they do. ${ }^{17}$ It is not merely about remembering the past or about historical information. The historical past is brought into "active dialogue with the present" (Perrin 2007:268), thereby allowing both the past and the present to be both challenged, transformed and enriched. It is, therefore, clear, that faith communities appreciated the powerful role of practices in their spiritual journey.

A significant aspect of this transformational power of practices throughout its history, is their dynamic nature. Practices are not static in the sense of being merely repetitive of ancient practices. A specific practice from the past might, for example, be considered unhelpful or irrelevant in a different context or group. Spiritual practices are, therefore, more than merely traditional activities that should be "kept" and "obeyed." They are indeed taken over as part of the church's heritage, but they are also modified, changed and adapted because of new contexts and participants that seek to experience the divine presence in terms of their particular situation. The latter remark is of utmost importance because of it reveals a salient aspect of their power: practices have an inherent power to reinvent themselves in the ongoing transformation of the spiritual life, ${ }^{18}$ because they are about "constituent elements in a way of life that becomes incarnate when human beings live in the light of and in response to God's gift of life abundant"

more accessible book, Studying Christian Spirituality (2007), which is the outcome of his long involvement in teaching spirituality to university students.

17 Perrin (2007:268) uses the example of the Roman Catholic practice of honouring the Sacred heart of Jesus, a late seventeenth century devotion, which many no longer uphold. When this devotion is understood in its historical context, as a call to "give one's heart to Christ", it makes a lot more sense.

18 Examples of such new or reshaped practices are contained in Taylor (2009). These include the practice of "wearing skin", the practice of "walking on the earth" and the practice of "getting lost". Bass and Dykstra (1997:20) state, "A practice can be almost any socially meaningful action" and should not be confined to the ancient exercises that were a part of monastic life or ascetic contexts. 
(Bass and Dykstra 1997:21) - and this happens in all times and places in a most relevant and powerful manner.

\subsection{The individual and communal nature of spiritual practices}

It is an important characteristic that spiritual practices are pursued in the first instance by individuals for their individual journey of faith, as has already been suggested by some of the remarks above. Some authors correctly note that this should not be confused with an individualistic lifestyle as if spiritual practices are exclusively individualistic. It is true that "practices are embodied by individuals" (Perrin 2007:269) and are undertaken by individuals alone, often and mostly in solitude, seeking connection with the Divine. And the many forms of spiritual practices confirm the individual nature of these practices. The mystical tradition is full of examples of individuals who practiced various forms and styles of prayer and meditation that yielded fruit for themselves and promoted their spiritual growth.

All this should, however, not negate or underplay their communal nature, context and consequences of spiritual practices. Spiritual practices are done also cooperatively; people can undertake them together as a community, and as such, they flow from or benefit the whole community. ${ }^{19}$ Spiritual practices such as worship services, baptism and bible studies are also the activities of communities. In addition, spiritual practices are the result of and promoted through the spiritual guidance and direction of churches. Individual experiences produce fruit, not merely for themselves, but also for their communities, past and present. The individuals' participation in inherited practices is, furthermore, affected by a communal setting because they are informed by the worldview and faith convictions of the communities of which individuals are members. This aspect of spiritual practices is important because it addresses the concern they are about individual and subjective experiences that privatise religion. They have,

19 Dykstra (1991:319) points out that when people are engaged in the spiritual practice of prayer, they may be doing so by themselves, but they are involved in a "coherent and complex form of socially established cooperative human activity." The interplay between individual and community is dynamic. The community forms the practice, the individual practices, the tradition is formed and passed on. Perrin (2007:270), similarly, and insightfully remarked, "Christian practices are always in communion with others - even if those others are not physically present." 
therefore, the power to influence the spiritual life of communities in a most comprehensive manner.

\subsection{The material nature of spiritual practices}

Spiritual practices find their power also in their embodied nature. In this regard it is of major consequence to understand what is meant by the notion of "spiritual" in spiritual practices. Sheldrake, in a concise reflection on the nature of spiritual practices, defines (2005:502) them as "ways in which a particular spiritual vision is both expressed and facilitated in patterns of behaviour, rituals, prayer or other religious disciplines." He adds (2005:503), though, that spiritual practices are also about mundane matters like justice, freedom and other socio-political issues. So that they have to do with "both a mystical and a prophetic-political faith." Being about "a way of life" or a "way of being in the world," they have a holistic, embodied character. One should not reduce practices to a set of rituals or privatise them as individualist experiences. He thus cautions against limiting them to an excessive interiority and calls attention (2005:502) to the need to balance interior practices with those that encourage an engagement with the world. ${ }^{20}$ Christian practice should rather be understood as discipleship, "to seek to know Jesus Christ is always to follow him, and, in some sense, to seek to imitate his way." Spiritual practice offers a variety of ways to follow Christ, but these always involve a discipline that may be undertaken in everyday life. ${ }^{21}$ In this regard Dykstra and Bass (1997:8) point out, "our daily lives are all tangled up with the things God is doing in the world." Practices point to divine realities even in the most mundane of spheres.

20 With such remarks, he reflects long standing perceptions about the spiritual life, such as those of the thirteenth century mystic, Jan van Ruusbroec, who rejected an excessive emphasis on penitential practice or on the monastic life at the cost of life in the world and a mundane existence.

21 Cf. Wiseman (2005:305). He refers to Jan van Ruusbroec (1293-1381), a Flemish mystic who established an Augustinian priory near Groenendaal, Belgium, and who was known for his strong criticism of any privileging of certain practices. "Ruusbroec had no tolerance for the quietist tendencies of his day ... The Christian ideal was to be rooted in a blissful awareness of oneness with God but at the same time to 'go out to creatures in virtue and righteousness through a love that is common to all' (Espousals, book 2)" He locates the spiritual life firmly in this world and in relationship with all of creation. 
They are, therefore, not the privileged domain of a few elect, of some saints who seek perfection in withdrawing from the world.

This embodied nature of spiritual practices challenges traditional dualisms that distinguish between the body and mind, the sacred and secular and spirit and matter (Perrin 2007:270). What counts is whether the practice takes place where and when there is potential for wholeness and there can be transformation of the most mundane of experiences and contexts. ${ }^{22}$ Spiritual practices thus refer to the concrete and the embodied. They are neither abstract nor ethereal, neither world denying nor about escapist subjectivity. They are fully embodied, done by human beings in and through their bodies. ${ }^{23}$ Bass and Dykstra (1997:8) spell out the implications of this when they remark that practices "address fundamental human needs through human acts." These practices often involve the bodily senses, consisting of concrete, physical movement, the saying of words, the making of sounds, experiences of tasting and smelling. They do so in a complex manner, because the body carries with it a history, strengths and limitations. The embodied nature of spiritual practices points towards their complexity and variety. ${ }^{24}$

In her book with the telling title, An altar in the world, Barbara Brown Taylor (2009:xv) rejects an exclusive, elevated and exaggerated view of spiritual practices with her remark that "(t)he treasure we seek requires no lengthy expedition, no expensive equipment, no superior aptitude or special company." And then she remarks, "All we lack is the willingness to imagine that we already have everything we need." Practices do not have

22 Perrin (2007: 270) shows how this transformation is threefold: personal, communal and potentially for the practice itself. The matter of spiritual transformation is beyond the bounds of this article, although it is a well-developed theme in the study of spirituality. The process of spiritual transformation is like unto a journey of the individual, using practices to achieve greater wholeness: individually as a fully integrated self, in community transcending the alienation that separates us from fellow human beings, and then in relation to the Divine.

23 Perrin (2007:270) notes, "The role of the body in any spiritual practice ... is irreplaceable."

24 Different practices may appeal to different aspects of a person's personality or character at a particular moment in time or stage of life (Perrin 2007:271). Perrin (2007:271) compares the pilgrimage of El Camino de Santiago with the Spiritual Exercises of St Ignatius of Loyola which, while sharing many similarities like duration and practice of hospitality, appeals to different parts of the self. 
to operate in a special, exquisite, or sensational sphere, nor require special training. The most mundane of places or simplest of times provide space and opportunities for spiritual reflection and growth. ${ }^{25}$

This insight is in line with what Waaijman (2007:8-9), in his phenomenological analysis of spirituality, noted when he observed that spirituality is deeply interwoven with the world, in terms of body, clothes, food, house, work, property, place, economy, environment and nature. $\mathrm{He}$ writes, "In journals (for spirituality), the last decade this dimension became increasingly important." It is a ground-breaking change, representing a major shift from centuries of negative attitudes toward the world to a clearly positive relation. ${ }^{26}$ The power of spiritual practices is, therefore, not only in their transformational potential for spiritual existence, but also for one's existence in this world and in the body.

\subsection{The processual nature of spiritual practices}

It has been indicated above that spiritual practices have to do with discipleship, following Jesus and being moulded in the divine image. Practices are, therefore, about sanctification, that is, being part of a new, transformed life in holiness that is ultimately a gift of God. This is a golden thread throughout publications that were discussed above. Spirituality, as Waaijman noted (2006:13), is indeed about divine action that begins a relationship of God with humanity, ${ }^{27}$ but this relationship is transformative and, therefore, about a process that unfolds and that affects the spiritual life. The more one engages in spiritual practices during this process, the

25 This insight, for example, has been spelled out already in the seventeenth century in a booklet on the practice of the presence of God, by the Carmelite, Brother Lawrence (1985). Describing his life in a monastery, he drew attention how even the ordinary, everyday task of looking after a community of monks (by, for example, working in the kitchen and mending shoes), can be turned into a spiritual practice.

26 Waaijman (2007:9) refers to the works of Levinas, in which he describes the material culture as interiority. "The dwelling, which is the embodiment of being at home with oneself in enjoyment, constitutes the centre from the perspective of which labour, possession, intimacy, hospitality and contemplation are unfolded."

27 "The human pole is touched and made to tremble, applies itself to the search for God, devotes itself fervently to God, makes itself receptive and allows itself to be purified, appropriates God's life to itself, lets itself be transported outside of itself in love, and that on all levels of existence" (Waaijman 2006:13). 
better one can become at doing them and the more effective they can be in shaping us. ${ }^{28}$

Spiritual practices that are done continuously and with careful attention have the power to permeate the ongoing existence of believers and communities. They generate habits that sustain and consolidate faith, as is clear from James K. A. Smith's book, You are what you love. The Spiritual power of habit. Smith (2016:17) focusses on the notion of discipleship. Discipleship is, other than has been assumed in Protestant catechesis, more than just learning facts or adopting an alternative worldview. It is more "a matter of hungering and thirsting than of knowing and believing". ${ }^{29}$ It involves acquiring new habits $(2016: 24)^{30}$ which are done repetitively, usually because they are meaningful, and one wants to do them. There are several examples of practices, such as prayer, fasting, solitude, study of scripture, which one might find hard to sustain initially, and where one's attention might waiver, but when one continues to practice it, it becomes habitual. Eventually they are done without thinking as part of a lifestyle.

Spiritual disciplines are habits, practices and experiences that are designed to develop, grow, and strengthen certain qualities of spirit. They reinforce

28 It is interesting to note how the analysis of spiritual practices in an academic context also suggests that greater exposure to spiritual practices improves their efficient understanding and execution. Spiritual practices have been documented, written about, studied academically and, in many cases, they have "standards of excellence" (Perrin 1997:8). Perrin reflects on how spiritual practices may be studied in the classroom. He suggests a three-part process of such a study that measures practices: It involves moving from an academic knowledge of spiritual practice to a lived experience of practice. Then follows a critical reflection on whether spiritual practices are appropriate to the classroom and determining "how to measure the success of what is taught" (Perrin 2007:276).

29 Smith makes his case (2016:27) by appealing to the common experience of being convinced of something important in a powerful presentation or sermon but finding that intellectual assent is not enough to permanently affect behaviour. "It seems we can't think our way to holiness ... because you aren't just a thinking thing?” Elsewhere Smith (2016:30) notes, "Instead we need to embrace a more holistic, biblical model of human persons that situates our thinking and knowing in relation to other, more fundamental aspects of the human person".

30 These new habits and practices respond more directly to our longings and desires than to our need to understand. Campolo (2007:77) defines a holy habit as an action "done intentionally, over time with regularity, with the goal of being formed into Christlikeness and with the result (fruit) of growing in love for God and others." 
what one believes ${ }^{31}$ and serve to embed faith more deeply. ${ }^{32}$ This is not about moralising the spiritual life. "Virtues may be learned and acquired through imitation and practice" (Smith 2016:66). "Virtues, quite simply, are good moral habits ... Good moral habits are like internal dispositions to the good - they are character traits that become woven into who you are so that you are the kind of person who is inclined to be compassionate, forgiving, and so forth" (Smith 2016:59). This is how practices can impact the person like the mere appropriation of convincing knowledge cannot do.

This has implications for spiritual formation programmes in which more effort will need to be given to practice than to merely information sharing. Christian formation could then be encouraged by offering participants opportunities to do things that will facilitate a closer walk with God. These practices as habits ${ }^{33}$ end up "recalibrating" ${ }^{34}$ a lifestyle and worldview. ${ }^{35}$ This approach appreciates the fact that the recalibration of a life happens not so much on the conscious level of cognitive understanding but on the unconscious level of our loves and desires (Smith 2016:102).

These insights reveal how practices empower the ongoing transformation of faith communities. They open the eyes for the realities of the spiritual

31 Volf (2002:254) notes that "Practices are essentially belief-shaped, and beliefs are essentially practice-shaping."

32 Paul understood the power of a habit to shape a person when he encouraged the Romans to adopt virtues such as refraining from adultery, murder, theft and covetousness together with adopting love for neighbour, behaving decently (Rom 13:814). He summarises the adoption of these virtues as "clothing ourselves with Christ." In Philippians 2:12-13, Paul presents the dialectic between the effort required by the believer who is "working out (her) salvation with fear and trembling", a process which inevitably involves obedience, and the work of God who "works in (her) to will and to act according to his good purpose."

33 Tony Campolo and Mary Albert Darling, in their book The God of Intimacy and Action. Reconnecting ancient spiritual practices, evangelism and justice, prefer the term "holy habits," stating, "Looking at the spiritual disciplines as practices or holy habits can take away possible off-putting connotations and motivate us to do them."

34 Smith (2016:75) uses this term "recalibrate" to refer to the process of "unlearning all the tacit bearings we've absorbed from other cultural practices" and to set a new direction for our loves and longings.

35 "The practices of the church are also a spiritual workout, inviting us into routines that train our heart muscles, our fundamental desires that govern how we move and act in the world" (Smith 2016:196). 
life, the need to face them with a spiritual approach and through concrete actions. At the same time they confirm that spiritual practice are about this world, but then always in terms of being open to divine action. This aspect deserves more attention now by analysing in what way one seeks a habitual praxis.

\subsection{Spiritual practices as reverence}

Although it is clear that practices are about action and effort, there is a recent development that illuminates their power in a special manner. Practices require a particular dedication - suggested by the many terms for practices like discipline, exercise and effort. Brown Taylor (2009:18-19) suggested that one form of practice is "paying attention" or "reverence." It is not per definition a religious practice. She links it with her personal experience of having been called up on the deck outside her parent's room, at night, with her sister, to observe a meteor shower. The observation of the natural phenomenon, and of the way her father experienced it, seemed to birth in her the beginnings of a ritual she then began to practice periodically throughout life.

I learned reverence from my father. For him, it had nothing to do with religion and very little to do with God. I think it might have had something to do with being a soldier, since the exercise of reverence generally includes knowing your rank in the overall scheme of things. From him I learned by example that reverence was the proper attitude of a small and curious human being in a vast and fascinating world of experience.

Paying attention involves for her the general experience of awe. It includes knowing how things work, including her own relation to each subject, but by times it also requires a careful, respectful approach, with due consideration to the intrinsic value of all things. ${ }^{36}$ She uses examples such as cleaning a rifle or dressing a wound (Brown Taylor 2009:20-21). It is, however, relevant for spiritual practices in so far as it requires one to set aside time, to stop all other activity, to still the mind, and to observe the minutest of objects

36 "Reverence stands in awe of something - something that dwarfs the self, that allows human beings to sense the full extent of our limits - so that we begin to see one another more reverently as well" (Brown Taylor 2009:21) 
and their features (Brown Taylor 2009: 22-23). Distractions must either be ignored or incorporated. One's attitude should be hospitable, grateful and curious. There should be a willingness to be led by the experience, not to seek to direct it. The practice cannot be rushed, and it requires surrender, giving up one's desire to control. This practice is not always easy. It can impose a burden when a painful truth can be exposed that may lead to our being confronted by an ethical dilemma or it may call for a change in behaviour on our part. It may very well be a spiritual tool facilitating further personal transformation.

There are similarities and links between paying attention with the ancient practice of discernment, discovering the will of God for the spiritual life. Discernment has to do with relating one's life to the movement of the divine in creation and community in order to be found in harmony with it. Paying attention relies on the same focus and observation in slightly different ways, but most of all, it, like discernment has to do with a complete awareness, with becoming conscious of what is there and what has been present all the time, but what has been obfuscated by the noise of one's alienated existence and one's self-occupied inbreeding. Discernment is the careful, concentrated awareness of the visitation of the divine in one' life in unexpected, minute ways. One discovers the divine will in a powerful way in a radical, trusting openness for the presence of God in the smallest, unexpected places and times. ${ }^{37}$ Without paying attention, awe for the divine presence in the world cannot be experienced.

\section{Spiritual practices and theology}

The above comments about the way in which spiritual practices are shared by and in all confessions, do not relativize the important role of theology in spiritual practices. Questions which explore practices are also theological and confessional in nature (Bass and Dykstra 2002:16). Whether practices emerge from a "quest for meaning" or as "a grateful human response to

37 Cf. Brown Taylor (2009:34). "Like all the other practices in this book, paying attention requires no equipment, no special clothes, no green fees or personal trainers. You do not have to be in particularly good shape. All you need is a body on this earth, willing to notice where it is, trusting that even something as small as a hazelnut can become an altar in the world". 
God's presence and promises", they shape lives by bringing the practice into a specific Christian tradition, so that, by implication, practices in some way or other will relate to confessional traditions, whether Protestant or non-Protestant. Sheldrake, for example, though emphasising (2005:502) that spiritual practices are determined by faith convictions and therefore cannot be divorced from belief systems, nevertheless cautions against overemphasise one pole above the other. This, by implication, means that one should also not ignore or downplay their confessional relevance. The following discussion will illustrate the role of theology and confessions in spiritual practices as it has been investigated in recent scholarship.

\subsection{Earning or effort?}

One of the most prominent features in the Protestant debate about practices, relates directly and importantly to a motif that is at the heart of the Protestant tradition. In his 2001 article, Live life to the full, the well-known Christian philosopher Dallas Willard confronts the typical Protestant protest that spiritual practices represent an attempt to earn salvation. Willard (1935-2013), ${ }^{38}$ a professor of philosophy and a leader from the conservative Southern Baptist tradition, was a prolific author on spiritual formation. His interest in practice was the result of his lived experience of a spiritual dryness that inhibited his personal spiritual growth. He found little comfort or inspiration in traditional convictions and activities. When he discovered the power of spiritual practices as solution to this exigency, he was faced with the challenges that they were not only peripheral to his tradition, but in many ways also unacceptable because they were regarded as illegitimate attempts to gain merit before God. In legitimizing his appropriation of practices, he resorted to a discussion of grace as a key

38 Willard wrote The Spirit of the Disciplines (1988), The Divine Conspiracy (1998) and Renovation of the Heart (2002) detailing his search for a viable process of Christian formation. In an interview with Stillpoint, a Journal compiled by Gordon College, Wenham, Massachusetts, Willard said: "Before I began studying the spiritual disciplines, I was reading St. Paul through the lens of dispensational theology. Basically, what that does, is relieve us of any genuine responsibilities to do anything except believe correct doctrine. That's important, but that's not life. I had to get past the idea that grace had only to do with forgiveness; that grace was opposed to effort - which it isn't; it's opposed to earning - and to understand the power of grace as an activity and a life that was difficult coming from the theological sources I had.” [Online]. Available: https:// www.gordon.edu/article.cfm?iArticleID =714\&iReferrerPageID =1676\&iPrevCatID =13 $4 \&$ bLive $=1$ 
Protestant theme. He characterizes the notion of grace in terms of effort and earning. Conceding that any notion of earning merit was taboo, he nevertheless writes,

The path of spiritual growth in the riches of Christ is not a passive one. Grace is not opposed to effort. It is opposed to earning. Effort is action. Earning is attitude (2001:1).

He then draws a distinction between practice as a vain effort to earn salvation and practice as a tool to devotion for growing closer to God.

As to "means of grace" placed in our hands, well-directed action is the key. The disciplines of the spiritual life are simply practices that prove to be effectual in enabling us to increase the grace of God in our lives (2001:1).

As if to drive his point home, he suggests (2001:1) that practices might very well be a means to orientate believers' lives toward the purposes of God, thereby opening themselves up to the Spirit's soteriological work.

That grace is, of course, "unmerited favour" (sic). But the form it takes is the action of God in our lives and with our actions. If we wish to know more of this and see the deliverance it works in and around us, we must do the things that will bring it to pass. These things are spiritual disciplines or the disciplines for the spiritual life.

Of special relevance is the remark that grace is about "the action of God in our lives and with our actions." With this remark, Willard may well reflect the important Protestant doctrine of sola gratia. But similar comments are made within Spirituality as a discipline by non-Protestant authors. In his comprehensive investigation of Spirituality, Waaijman, for example, stressed that spirituality is about the God's transformational relationship with humanity that unfolds during a long spiritual journey. The initiative for and the event of divine transformation which brings humanity to grow into and reflect the image of God, is solely with God and is bestowed as a gift to people. For Waaijman, this unmerited understanding is biblical in nature. He refers, for example, to Genesis 28:15, "I will be with you wherever 
you go and bring you back to this land; no, I will not leave you." ${ }^{39}$ He writes (2002:885) how an encounter with God comprehensively affects someone's life pattern and language, influences the will, and how this divine touch "takes the initiative away from him or her." It is the touch of God which brings salvation.

The encounter with God touches the heart, awakens in it hidden capacities, opens it up, draws it out of itself, recollects it, heals its brokenness, reveals hidden sides, challenges one to grown, teaches on how to liver through pain, leads one into a new life.

It is, though, not only a biblical motif. Waaijman (2002:912) also refers to John of the Cross as a classic spiritual author, who spoke of the spiritual leader in his Living flame of love as someone who is ultimately brought to give up on the finite in order to be filled by the Infinite. This surrender is not a human intervention. It happens when someone is touched by God. John of the Cross writes, "the soul, then, should advert that God is the principle agent in this matter, and that He acts as the blind man's guide who must lead it by the hand to the place it does not know how to reach" (III, 29). What is true of mystagogue, is, mutatis mutanda, true for the spiritual pilgrim. People receive the divine grace in their quest for sanctification. God's holiness is profiled in their desire and quest for holiness (Waaijman 2006:13). Their sanctification is not because of human initiative, nor is it the end goal. What begins with God, ends with God. Sanctification is merely the way that one journeys from, with and then back to God. The gift of God's grace that people receive passively, becomes their active response to God. There is a reciprocity that has as result that God and humanity are intimately connected, to such an extent that the response is nothing else but God's work. God is at work through spiritual practices, and they are meant to be open to and aware of the divine presence. Or, in Waaijman's words (2006:13), the fear of God (that is also at work in spiritual practices) "trembles at the Secret to which it reaches out."

39 Cf. Waaijman (2002:64) for other examples. Cf. also Waaijman (2019), "Mystical transformation leads us from our temporal-spatial self-centeredness into the free space of God's love. Essentially, this process is seen from our human perspective, a process of letting go, of giving over the initiative to God. This is about a training in trust and at the same time, basically, a training in prayer: 'Take over, my Lord, what I am doing."' 
Waaijman's comments relate to spirituality as it functions in all confessions and confirm Willard's understanding of grace. There is no indication of merit or earning through spiritual practices. And yet, Willard, belonging to the orthodox Southern Baptist tradition with its keen awareness of God's saving grace, uses a key Protestant theme of grace to justify his use of spiritual practices, nuancing them with his distinction between earning and effort. Ultimately, his apology for practices is offered in dialogue with his Protestant tradition. Though Willard and Waaijman share some profound common insights about the divine role in spiritual practices, the language with which they speak differ in terminology and focus. One recognises in Waaijman's language, for example, the strong contemplative tenor that characterizes the Carmelite tradition, whilst Willard's language about "effort" seems to be implicitly imbued with the tenor of Protestant work ethic. ${ }^{40}$

\subsection{Justification and sanctification}

Willard's important reflections on spiritual practices that deny any notion of earning grace, can be complemented by other examples of other Protestant themes that influenced the interest in spiritual practices. It is to be expected that the confessional nature of practices will be more evident in cases where there is a stronger theological reflection. An illuminating example is to be found in an experiment undertaken by Serene Jones on a local level within her church, a Protestant faith community and described in her publication on the matter (Jones 2002:52). This experiment began as an idealistic listing of all the activities that the congregation wanted to do in their community. Soon, however, fatigue set in among its members as they became reluctant to become involved in church activities that would leave them feeling even more worn out than before. One notes in this description some of the alienation pointed out by Willard in his ministry. The group then undertook a strategic planning session what it means to be church and the relationship between being and doing as God's people.

Significantly they began this session from their confessional perspective, particularly the spiritual practice of discernment. They wanted to discern the way forward by, in true Protestant sense, listening to the "Word." Their

40 Hence his reference to John of the Cross. 
reflection was, however, filled in with the two key notions of justification and sanctification as part of the fundamental theme of grace. Understanding that being justified is about "grace that frees" and that it happens as a free gift of God, they agreed that they did not need to "earn" God's favour. They then confirmed sanctification as a second key Protestant term in their confessional tradition which they interpreted, in the words of Jones (Jones 2002:58) as "the grace that forms". Following Calvin's thinking on the relationship between justification and sanctification, they furthermore deduced that these were not two sequential processes, but rather two dimensions of a single divine action (Jones 2002:59). Believers are being freed and, at the same time, also shaped by grace. Practices are "what we become as we are set in motion in the space of doctrine" (Jones 2002:75-76).

Practitioners, furthermore, should seek to be excellent in their practices as an expression of love for God. Being saved as a result of God's favour and as a gift, means that practices cannot refer to their capacity to "earn" God's favour, but are simply “joyous, celebratory gestures” (Jones 2002:66). This did involve discipline and effort, but, at the same time, practices should be undertaken joyfully as befitting of activities that are life-giving. Accentuating the joyful nature of spiritual practices, they confirmed glorification of God as another key Protestant theme.

This experiment with its reflections as reported by Jones, is indeed illustrative of the Protestant preoccupation with and focus on themes like justification and sanctification. At the same time, the experiment confirms the dynamic process: relatively marginal spiritual practices are taken over by a Protestant community in a new dispensation. In doing so, spiritual practices are liberated from Protestantism's earlier, restrictive and hostile understanding. This experiment reveals a recognition that Christianity shares a common heritage that are foundational for the life of the church in times of alienation, feelings of desperation and a desire for transformation and renewal.

\section{Conclusion}

The above comments have illustrated that the growing interest of Protestants is driven by the realisation that there are practices that transcend denominational borders, that these are not necessarily contradictory to 
their own confessional traditions, and that they are, in fact, in line with key elements of that tradition. It confirms how ancient traditions of both Protestants and Roman Catholics blend in with their particular theological and denominational traditions. The Protestant appreciation of spiritual practices is no longer burdened by simplistic theological prejudices and uninformed, superficial understandings of spiritual practices. To the contrary, Protestantism has discovered that spiritual practices are part of its rich heritage that has deep roots in early Christianity. In fact, the above analysis indicates how careful scholarship applied its critical skills to move beyond the bitter confrontational confrontations of earlier times to rediscover spiritual traditions that are transformative and life giving.

The Protestant Reformation of the sixteenth century was a watershed moment for the church. The rise of the working classes, the proliferation of printed publications, and the dissatisfaction of many ordinary believers with a liturgical structure that excluded them from participation lit a tinder box of religious fervour. This coupled with a popular uprising against the practice of selling indulgences and the abuse of the poor through the imposition of penance and the use of Latin as a liturgical language, caused many to call for a Reformation.

Protestants sought to return to the basics of faith, naming them as Christ alone, Scripture alone and salvation through faith alone. The sifting process was radical, and many meaningful practices were turfed out of church life because they were perceived to be ways of earning salvation. There are, however, a growing trend that reflects a reconceptualization of spiritual practices as sanctifying activities with biblical roots, more directed at developing a closer walk with God, than "earning" God's favour. Spiritual practices powerfully appeal more to the desires of the faithful rather than to convince the mind, and that by doing so, practices become habits that empower and shape spiritual lives. Also significant is how dynamically spiritual practices can speak to faith communities in language in which they were born, shaped and empowered. 


\section{Bibliography}

Assohoto, B. and S. Ngewa, 2006. Genesis. In T. Adeyemo (ed.). Africa Bible Commentary. Nairobi: Word Alive.

Allender, D.B. 2009. Sabbath. Nashville: Thomas Nelson.

Bass, D.C. 1997. Keeping Sabbath. In C. Dykstra and D. Bass (eds.). Practicing our faith. A way of life for a searching people. San Francisco: John Wiley. 75-89.

- 2000. Receiving the day. Christian practices for opening the gift of time. San Francisco: Jossey-Bass.

Bass, D.C. and C. Dykstra. 2002. A theological understanding of Christian practices. In D.C. Bass, and M. Volf. Practicing theology. Beliefs and practices in Christian life. Grand Rapids: Eerdmans.

Brown Taylor, B. 2009. An altar in the world. A geography of faith. New York: Harper Collins.

- 2014. Learning to walk in the dark. New York: HarperCollins.

- 2019. Holy Envy. Finding God in the faith of others. Norwich: Canterbury Press.

Brother Lawrence. 1985. The practice of the presence of God. Orleans: Paraclete Press.

Brueggemann, W. 1982. Genesis. A commentary in the Interpretation series. Atlanta: John Knox Press.

- 2014. Sabbath as resistance. Saying no in a culture of now. Louisville: Westminster John Knox.

Butler Bass, D. 2004. The practicing congregation. Imagining a new old church. Durham: Alban Institute.

Butler Bass D. and J. Stewart-Sicking, J. (eds). 2006. From Nomads to pilgrims. Stories from practicing congregations. Durham: Alban Institute. 
Campolo, A. and M.A. Darling. 2007. The God of Intimacy and action. Reconnecting ancient spiritual practice, evangelism, and justice. San Francisco: Jossey-Bass.

DeWaay, B. 2005. The Dangers of Spiritual Formation and Spiritual Disciplines. A critique of Dallas Willard and the Spirit of the Disciplines. Critical Issues Commentary, 91. [Online]. Available: https://cicministry.org/commentary/issue91.htm. [Accessed: 11 February 2020].

Driskill, J.D. 1991. Protestant spiritual exercises. Theology, history and practice. New York: Morehouse.

Dykstra, C. 1991. 'Reconceiving practice in theological enquiry and education'. In B.G. Wheeler and E. Farley. Shifting boundaries. Contextual approaches to the structure of Theological Education. Louisville: Westminster John Knox Press, 35-66.

Dykstra, C. and D. Bass (eds.), 1997. Practicing our faith. A way of life for a searching people. San Francisco: John Wiley.

Foster, R.J. 1978. Celebration of discipline. The path to spiritual growth. New York: HarperCollins.

Herschel, A.J. 1951. The Sabbath. Its meaning for modern man. New York: Farrar, Straus and Giroux.

Jones, S. 2002. Graced practices: Excellence and freedom in the Christian life. In D.C. Bass and M.Volf. Practicing theology. Beliefs and practices in Christian life. Grand Rapids: Eerdmans.

Jones, T. 2005. The Sacred way. Spiritual practices for everyday life. Grand Rapids: Zondervan.

McLaren, B.D. 2008. Finding our way. The return of the ancient practices. Nashville: Thomas Nelson.

Norheim, B.E.H. 2014. Practicing baptism. Christian practices and the presence of Christ. Eugene: Pickwick.

Olson, D.T. 2008. Sacred Time: The Sabbath and Christian worship. In C.M. Bechtel (ed.). Touching the altar. Grand Rapids: Eerdmans. 
Perrin, D. 2007. Studying Christian spirituality. New York: Routledge. Sheldrake, P. 1995. Spirituality and history. Questions of interpretation and method. Revised edition. London: SPCK.

- 1999. 'The study of spirituality in Theological Trends'. The way, 39/2.

- 2005. 'Spiritual Practice'. In P. Sheldrake. The Westminster dictionary of Christian Spirituality. Louisville: Westminster, 502-503.

Smith, J.K.A. 2016. You are what you love. The spiritual power of habit. Grand Rapids: Brazos Press.

Volf, M. 2002. 'Theology for a way of life'. In D.C. Bass and M. Volf. Practicing Theology. Beliefs and Practices in Christian Life. Grand Rapids: Eerdmans.

Waaijman, K. 2002. Spirituality. Forms, Foundations, Methods. Leuven: Peeters. 869-945.

- 2006.'What is Spirituality?' Acta Theologica Supplementum 8.

- 2007. 'Spirituality - A Multifaceted Phenomenon'. Studies in Spirituality, 17:1-113.

- 2019. 'Uninterrupted prayer - A-spiritual challenge'. HTS Teologiese Studies/Theological Studies 75(4):a5578. [Online]. Available: https:// doi.org/10.4102/hts.v75i4.5578

Wakefield, G.S. 1983. 'Spirituality'. In G.S. Wakefield, ed. The Westminster dictionary of Christian spirituality. Philadelpia: Westminster Press. 361-363.

Williams, A. 2016. 'Spiritual landscapes of Pentecostal worship, belief, and embodiment in a therapeutic community: New critical perspectives'. Emotion, Space and Society, 19(2016):45-55.

Willard, D. 1998. The Divine Conspiracy. Rediscovering our hidden life in God. San Francisco: Harper One.

- 2001. Live life to the full. Christian Herald, 14 April 2001. 
